\title{
Immigration in the United States 2016 Presidential Debates: A Functional Analysis
}

\author{
Ahmed Hasani Yaseen ${ }^{1}$, Afida Mohamad Ali2*, Zalina Mohd Kasim ${ }^{1}$ \\ 1Department of English, Faculty of Modern Languages and Communication, University Putra Malaysia, Malaysia \\ 2Department of Translation, Faculty of Arts, University of Tikrit, Iraq
}

Corresponding Author: Afida Mohamad Ali, E-mail: afida@upm.edu.my

\section{ARTICLE INFO}

\section{Article history}

Received: November 17, 2017

Accepted: January 06, 2018

Published: May 01, 2018

Volume: 7 Issue: 3

Advance access: March 2018

Conflicts of interest: None

Funding: None

\begin{abstract}
This paper describes an analysis of the three U.S. 2016 presidential debates published in The New York Times using Benoit's (2007a) functional theory. The three presidential debates in the U.S., which occur every four years, remain as the most sensitive political rhetoric that lead to the election of the next U.S. President. These debates include discussion of different issues between the two presidential candidates. One of these issues is immigration. The U.S. presidential debates have been researched by many on various aspects but there has not been a study that focus primarily on the issue of immigration in the three 2016 U.S. presidential debates. All statements regarding this issue between the two presidential candidates, Trump and Clinton, were extracted from these debates and analyzed using Benoit's (2007a) functional theory. Findings revealed that attack statements occurred more than acclaims, and defences were less used than acclaims. The statements included in these debates pertained to policy (30\%) and character (70\%). As expected, general goals were employed more often using acclaim function rather than attack and defend. However, ideals were employed more often using defence than to acclaim and attack. Due to different contexts, situations, and participants, Benoit's (2007a) functional theory may not be generalized for all debates. This study reveals certain inconsistencies regarding some of the hypotheses of Benoit's (2007a) functional theory in relation to our knowledge of the presidential debates, specifically the issue of immigration.
\end{abstract}

Key words: Presidential Debates, Immigration, Functions, Topics, Policy Forms, Character Forms

\section{INTRODUCTION}

In the 2016 U.S. presidential debates, immigration is one of the top most significant issues for both Hilary Clinton and Donald Trump and it is that which also separates them. Observations by Merelli (2016) suggest that various issues as mentioned below, have been debated by the two presidential candidates, the Democrat Hilary Clinton and the Republican Donald Trump, in the 2016 U.S. presidential debates. The issues in the first debate are namely, Achieving Prosperity; America's Direction; and Securing America. The second debate involves the following issues: The Affordable Care Act; Islamophobia and Syrian refugees; WikiLeaks and taxes; the war in Syria; Leadership and 'deplorable'; the Supreme Court, energy policy, and compliments. While the third debate includes The Supreme Court; national debt, global trade, and jobs; sexual allegation and the Clinton foundation; immigration; foreign hot spots (Russia and WikiLeaks); each candidate's fitness to be president (transition of power).

Many researchers have extensively studied the diverse aspects or issues in the three U.S. 2016 presidential debates. However, less attention has been given on the issue of immi- gration in these three debates. The research focuses on this issue rather than the other argued issues as it is a humanitarian issue and one of Trump's top interesting issues (Caldwell \& Timm, 2016). In spite of the United States of America being a nation of immigrants (The New York Times, 2016c), there are certain activities which are against immigrants such as deportation by force, abuse, ripping families apart, bashing, exploitation, describing some as drug suppliers, offenders, and rapists. This study suggests that the issue of immigration is the issue that most people should take into consideration due to the reasons mentioned above.

The issue of immigration has a pivotal role in the U.S. presidential debates. It has received significant critical attention as it is becoming really problematic to disregard the presence of immigrants. This is because there has been an increased concern that some immigrants are being disadvantaged (The New York Times, 2016c).

In the literature on such debates, the relative importance of the issue of immigration has been subjected to substantial discussion. Although some research have been carried out on the 2016 U.S. presidential debates, there have been rare 
investigations into this issue. It is unknown whether or not Benoit's (2007a) functional theory is applicable to all issues mentioned in the 2016 U.S. presidential debates. Despite the importance of this theory, there remains a paucity of evidence on the inconsistency of some hypotheses of Benoit's (2007a) functional theory in terms of the issue of immigration in these debates.

This study aims to test the practicability of using the functions and topics of Benoit's (2007a) functional theory on the speeches of the two candidates regarding the issue of immigration in these debates. According to the hypotheses of this theory, the current study first determined the debated issues in the three presidential debates. The criteria (functions and topics) of this theory are then applied to the issue of immigration to detect the theory's adequacy based on Cronbach's alpha test statistic. This study is of the opinion that some hypotheses of functional theory designed for this application are inadequate for certain issues presented in presidential debates but appropriate for others.

The purpose of the present research is to analyse the issue of immigration in the 2016 U.S. presidential debates by using Benoit's (2007a) functional theory. The research data in this study is drawn from the 2016 U.S. presidential debates published in The New York Times (2016). It does not, however, engage with other issues discussed between Trump and Clinton throughout these debates.

The overall structure of this paper is divided into five sections. The first section presents the literature review and related past studies. Section two illustrates Benoit's (2007a) functional theory as a model used in analyzing these debates. While scheme of analysis denotes section three which describes the methods used in the analysis. Section four details the findings and discussion of this study, whereas section five presents the conclusion.

\section{LITERATURE REVIEW}

A significant amount of literature has been published on the U.S. presidential debates. The last 20 years have witnessed increasing information on the implementation of Benoit's (2007a) functional theory on presidential debates. Most researchers who have investigated the presidential debates utilize this particular theory. These studies discuss diverse issues from different points of view e.g. Jacobs and Ceaser (2016) have dealt with 'numbers in historical perspective'; Quam and Ryshina-Pankova (2016) addressed 'the manners that Donald Trump, Hillary Clinton, and Bernie Sanders arranged themselves with their people'. The issue of 'health care policy' is also central and was conversed in the 2016 U.S. presidential campaign (Blendon et al., 2016). Moreover, in 2016, Clarke and Ricketts declared that the U.S. 2016 presidential election returns the American foreign policy to the 'Jacksonian tradition'. On top of that, in 2016, Ghayad et al. focused on both candidates' ignorance to U.S. "economy and recessions". Other studies investigated 'unexpected gender gap' like Burden, et al. (2016). On the same vein, 'digital and online platforms' is a topic which Powers, et al. (2016) examined, and not forgetting analysis of 'social media platform' by Enli (2017). A significant analysis and discussion of a study, which is the 'unexpected victory' presented by Huang (2017), paid attention to many observers. In these debates, the 'false news stories' have been considered by Allcott and Gentzkow (2017), while Harnish (2017) pursued about 'disabilities people'. One study by Slutsky and Gavra (2017) scrutinized the case of 'Trump's popularity in Russia through the examination of media perspective". On the other hand, Crowson and Brandes (2017) explored many facets of 'the right-wing authoritarianism and social-dominance orientation'. Depending on personality trait of self-monitoring, the 'social desirability' in the U.S. 2016 presidential election campaign was the main concern of Klar et al. (2017). Together these studies provide important insights into the issues argued in the U.S. 2016 presidential debates.

\section{THE FUNCTIONAL THEORY OF POLITICAL CAMPAIGN DISCOURSE}

One of the greatest used theories in the studies on presidential debates is the functional theory of political campaign discourse. In the 1990s, Benoit and Wells analyzed 'Keynote Speeches from 1960-1996' and 'Nomination Convention Acceptance Addresses from 1960-1996' by means of the functional theory of political campaign discourse. They continued their research on TV ads and appearances on talk radio as well as many presidential debates. In addition, they also analyzed other presidential TV spots during 1952-1996 and presidential debates during 1948-2000 (Benoit, 2007a). This theory has gradually evolved and been improved by some scholars such as Benoit, Brazeal, Stein, Pier, Harthcock, Blaney, and others. Benoit (2007a) is recognized as the pioneer and developer of this theory. Two main aspects, which are function and topic, make this theory the most appropriate one for political campaign discourse. With regards to the first aspect, i.e. function, in order to win a presidential election, this theory posits that a candidate has to appear in a preferable form than the other candidate. Three functions: acclaim, attack, and defence can serve as messages for giving hope to a candidate to be preferable to opponents (Benoit, 2017). These functions, in accordance with Benoit and Airne (2005), work together as an informal procedure of cost-benefit analysis: acclaims raise benefit, attacks raise a rival's cost, and defences decrease a candidate's suspected cost. An acclaim is considered as a positive utterance for a candidate; an attack is regarded as paying attention to a drawback or negativity of a foe; a defence is to refute an attack that is directed to the defending candidate (Benoit, 2017). Moreover, Reinemann and Maurer (2005) assure that, in debates of German politicians, acclaims are suitable to uphold the candidates' utterances or statements, while the candidates' attacks are served to polarize the voters.

The second aspect of this theory, i.e. topic, is concerned with two aspects: policy and character. Benoit's (2007a) functional theory assumes that these topics are mainly discussed in political election campaign. Policy and character are used by candidates to convince audience to elect their preferable candidate. Zarefsky (2016) affirms that this theory is designed to show that the candidate's functional mes- 
sages are created to convince voters in which certain candidates gain more preference, approval, and acceptance than other rivals.

One of the two topics of functional theory is policy, which is classified into three subclasses that enable candidates to acclaim, attack, or defend past deeds (governmental actions done by the candidate or his/her government), future plans (precise commitments or promises that candidates will follow in case they elected or re-elected), or general goals (talking about results rather than means, and no information about the candidates' proposals). From the other point of view, character (some scholars call it image) as a topic, consists of three entities: personal qualities (that is empathy, honesty, and morality), leadership ability (is the candidate able to administer the government? Or is the candidate successful in business), and ideals (values and principles of the candidate) (Benoit, 2007a).

The functional theory pays attention to the messages which are created, produced, or designed rather than the way that voters' receive messages whether convincing or not. Consequently, four hypotheses with two research questions are investigated in the present study on the issue of immigration in the 2016 U.S. presidential debates using Benoit's (2007a) functional theory. They are as follows:

Hypothesis 1: In the issue of immigration by Trump and Clinton, acclaims occur more regularly than attacks and defenses have the least occurrence.

Often in such presidential debates, acclaims happen more than attacks, but defenses occur less than attacks. For the candidates, no restrictions are given to say or express their messages to convince the voters. Some candidates may be an exception with the possibility of using acclaim more than attack.

In reference to policy and character, there is a belief that candidates follow the policy of their parties. In other words, the candidates are prepared early to a certain policy formulated, required, and implemented by their parties. Public opinion ballots state that most voters announce that they will elect the one who has central policy (Benoit, 2003). Hence, the second prediction is that:

Hypothesis 2: Trump and Clinton talk about policy more regularly than character in the immigrants' issue. In fact, these two candidates deliberately address policy more than character. No doubt, some exceptions may happen for the candidates.

Policy and character are analysed in relation to three functions: acclaim, attack, and defence which can be seen in the two research questions below:

Research Question 1: How is the distribution of the three functions in addressing policy with regards to issues of immigration?

Research Question 2: How is the distribution of the three functions in addressing character with regards to issues of immigration?

General goals which are associated to the form of policy, and ideals which are interrelated to the form of character, deal with the third and fourth hypotheses respectively.

Hypothesis 3: General goals are utilized by Trump and Clinton more often to acclaim than to attack immigrants' issue.
Hypothesis 4: Trump and Clinton utilize ideals most of the time to acclaim as compared to attack or defend immigrants' issue.

To enhance our understanding of the nature of immigrants' issue, it is necessary to analyze the speeches of Trump and Clinton about immigrants according to these hypotheses.

\section{SCHEME OF ANALYSIS}

In this study, the immigration issue in the three 2016 presidential debates in U.S. were analysed. The speeches that are represented here are the utterances of the two presidential candidates, the Democrat candidate Clinton and the Republican candidate Trump. Firstly, the themes of each debate were determined. Each theme contains many utterances which are differentiated in length (some utterances are phrases, sentences, while others are full paragraph). The two candidates' utterances were analysed and labelled by function: acclaim, attack, or defence. Then, data was further analysed to determine whether it was related to policy (issue) under its forms (future plans, past deeds, or general goals) or character (image) under its forms (leadership ability, personal qualities, or ideals).

Inter-rater reliability statistics is performed to ensure consistency and dependability of the data used in this study. For this, the data was analysed by two raters. Table 1 below shows the result of the reliability test and as a rule of thumb, the average.940 of Cronbach Alpha value is found highly reliable as stated in Table 1. Based on the results, all the pairs achieved outstanding agreement on the Cronbach's Alpha, which ranged from 0.835 to 1.00 .

The sampling was purposive where it collected and analysed the three 2016 U.S. Presidential Debates.

\section{FINDINGS AND DISCUSSION}

The functional analysis of the actual excerpts from the two candidates' speeches, which are related to the issue of immigration in the 2016 U.S. presidential debates, is going to be illustrated using selected examples chosen from the three debates. The distribution of functions in the three debates is the main concern of the first hypothesis. Acclaims which are

Table 1. Reliability statistics

\begin{tabular}{llcc}
\hline $\begin{array}{l}\text { No. of } \\
\text { raters }\end{array}$ & Variables* & No. items & Cronbach's alpha \\
\hline 2 & A1 vs A2 & 56 & 0.987 \\
2 & B1 vs B2 & 56 & 0.835 \\
2 & C1 vs C2 & 56 & 0.934 \\
2 & D1 vs D2 & 56 & 1.000 \\
2 & E1 vs E2 & 56 & 0.979 \\
2 & F1 vs F2 & 56 & 0.860 \\
2 & G1 vs G2 & 56 & 0.989 \\
2 & All & 56 & Average 0.940 \\
\hline
\end{tabular}

* A: policy, B: character, C: acclaim, D: attack, E: defence, F: Benefit, G: cost, 1: the first rater, 2: the second rater 
one of these functions can be seen in the following selected examples:

E.g. (1) Clinton: 'I have been for border security for years. I voted for border security in the United States Senate. And my comprehensive immigration reform plan of course includes border security. But I want to put our resources where I think they're most needed: Getting rid of any violent person. Anybody who should be deported, we should deport them" (The New York Times, 2016c).

In these sentences, Clinton tries to describe her past good deeds and achievements as a secretary for many years as well as many respectable and reasonable plans she tends to fulfil in the next future. Consequently, Clinton increases her benefit in this acclaim.

Moreover, the following statements in the second example state how Trump explores his positive aspects where he has gained the approval from more than 16,500 agents in U.S. Immigration and Customs Enforcement. He illustrates that, previously, those agents had never endorsed any presidential candidate at all. This signifies that they support his strategies as the next U.S. President. As a result, Trump raises his benefit by this acclaim.

E.g. (2) Trump: "The border - as you know, the Border Patrol agents, 16,500-plus ICE last week, endorsed me. First time they've ever endorsed a candidate. It means their job is tougher. But they know what's going on. They know it better than anybody" (ibid.).

On the other hand, the following samples represent attack which is another function included in the issue of immigration in these debates.

E.g. (3) Trump: "In a place like Chicago, where thousands of people have been killed, thousands over the last number of years, in fact, almost 4,000 have been killed since Barack Obama became president, over - almost 4,000 people in Chicago have been killed" (The New York Times, 2016a).

This example indicates that Trump attacks Clinton by describing the negative events that happened during the period of President Obama, her colleague in the Democrat Party. This attack reduces Clinton's benefit by insinuating the poor governance of the Democrat leader and hence, presupposes a need for change.

Yet, Clinton attacks Trump in example (4) claiming that he condemns immigrants especially Mexicans, and has an opposite view from her in dealing with immigrants. He describes them as breaching the American law. This attack decreases Trump's benefit.

E.g. (4) Clinton: "But it is clear when you look at what Donald has been proposing, he started his campaign bashing immigrants, calling Mexican immigrants rapists and criminals and drug dealers, that he has a very different view about what we should do to deal with immigrants" (The New York Times, 2016c).

Defences signify the last function imbedded in the three presidential debates. Three samples illustrate this function:

E.g. (5) Clinton: "Well, within hours I said that I was sorry about the way I talked about that, because my argument is not with his supporters" (The New York Times, 2016b).

Clinton, in example (5), identifies Trump's attack; defends herself by apologizing as a reaction to his attack which was aimed to lessen Clinton's cost.

While Trump, in example (6), defends himself as a reaction when Clinton attacks him regarding the issue of the undocumented labour in which Trump underpaid undocumented workers. Such a defence may lessen Trump's cost.

E.g. (6) Trump: "President Obama has moved millions of people out. Nobody knows about it, nobody talks about it. But under Obama, millions of people have been moved out of this country. They've been deported. She doesn't want to say that but that's what has happened and that's what happened big league" (The New York Times, 2016c).

The analysis of the debates regarding the issue of immigration revealed that acclaims accounted for $34 \%$ of the utterances of the two candidates (50\% for Trump versus 50\% for Clinton) while attacks comprised $47.5 \%$ (61\% for Trump versus 39\% for Clinton) and defences achieved 18.5\% (42\% for Trump versus $58 \%$ for Clinton). These findings illustrated in Table 2 are contrastive with the first hypothesis. With regards to the comparison between the occurrence of acclaims and attacks, the first hypothesis is partially not supported.

The prediction of the second hypothesis is that the two candidates discuss policy more regularly than character. Two selected samples are shown below expressing the policy issue:

E.g. (7) Trump: "I'm going to help the African-Americans. I'm going to help the Latinos, Hispanics. I am going to help the inner cities" (ibid.).

This excerpt characterizes Trump's policy in which he intends to provide assistance to various American ethnic folks as well as people who are in need of help in the American inner cities. In this example, Trump defends himself also and lessens his alleged cost.

With regards to Clinton, the illustration in the eighth example shows how Clinton employs the policy issue by communicating her ability in leadership as an American president. In this example, according to Clinton's slogan (Stronger Together) in her political campaign, she expresses

Table 2. Functions and topics concern the issue of immigration

\begin{tabular}{|c|c|c|c|c|c|c|c|c|c|c|}
\hline \multirow[t]{3}{*}{ Total } & \multicolumn{6}{|c|}{ Functions } & \multicolumn{4}{|c|}{ Topics } \\
\hline & \multicolumn{2}{|c|}{ Acclaims } & \multicolumn{2}{|c|}{ Attacks } & \multicolumn{2}{|c|}{ Defences } & \multicolumn{2}{|c|}{ Policy } & \multicolumn{2}{|c|}{ Character } \\
\hline & $\mathrm{T}$ & $\mathrm{C}$ & $\mathrm{T}$ & $\mathrm{C}$ & $\mathrm{T}$ & $\mathrm{C}$ & $\mathrm{T}$ & $\mathrm{C}$ & $\mathrm{T}$ & $\mathrm{C}$ \\
\hline & 11 & 11 & 19 & 12 & 5 & 7 & 18 & 13 & 33 & 39 \\
\hline & $50 \%$ & $50 \%$ & $61 \%$ & $39 \%$ & $42 \%$ & $58 \%$ & $58 \%$ & $42 \%$ & $46 \%$ & $54 \%$ \\
\hline & \multicolumn{2}{|c|}{ (22) $34 \%$} & \multicolumn{2}{|c|}{ (31) $47.5 \%$} & \multicolumn{2}{|c|}{ (12) $18.5 \%$} & \multicolumn{2}{|c|}{ (31) $30 \%$} & \multicolumn{2}{|c|}{ (72) $70 \%$} \\
\hline
\end{tabular}

T: Trump; C: Clinton 
her intention in having all ethnics, religions, and traditions in America to be an integrated country unlike Trump's claim against people from different ethnics that would disrupt a lot of families in America. In addition, Clinton's utterance in this instance can be considered as an attack which reduces Trump's benefit.

E.g. (8) Clinton: "I think that is an idea that is not in keeping with who we are as a nation. I think it's an idea that would rip our country apart" (ibid.).

Selected examples will be explained to reveal the images of the character. These are:

E.g. (9) Trump: "We need law and order in our country" (The New York Times, 2016a).

The above example illustrates the leadership ability of Trump and his strong character when he announced that law and order must be applied in America. This declaration is reckoned an acclaim as well which increases Trump's benefit.

In addition, Clinton in the following example enunciates herself as an ideal character. She is compassionate with people that Trump had not apologized for. An attack from Clinton against Trump is also shown in this situation which leads to minimize Trump's benefit.

E.g. (10) Clinton: "And what he has said about African-Americans and Latinos, about Muslims, about POWs, about immigrants, about people with disabilities, he's never apologized for" (The New York Times, 2016b).

The findings from the study revealed that character $70 \%$ (46\% for Trump versus 54\% for Clinton) was discussed more than policy $30 \%$ (58\% for Trump versus $42 \%$ for Clinton). These findings Table 2 do not support the second hypothesis.

The rate of occurrence for forms of policy (past deeds, future plans, and general goals) are examined in the first research question. Some examples are stated below:

E.g. (11) Clinton: "I voted for border security, and there are. There are some limited places where that was appropriate" (The New York Times, 2016c).

E.g. (12) Trump: "First of all, I had a very good meeting with the president of Mexico" (ibid.).

According to these examples $(11,12)$, both candidates mention their past deeds where example (11) identifies Clinton's past deed that she has voted for border security. Moreover, this example gives an indication to the acclaim function which in turn increases Clinton's benefit. From the other point of view, example (12) designates Trump's past deed of his fruitful meeting with the Mexican president. In this situation, Trump's articulation embodies both functions of acclaim and defence which increases the benefit of Trump and lessens his cost respectively.

With respect to the policy of future plans, examples (13, 14) illustrate both candidates' plans in the future. Example (13) specifies Clinton's plan where she intends to make reforms in various aspects. Simultaneously, this example employs the functions of acclaim that increases Clinton's benefit and attack which reduces Trump's benefit. Hitherto, in example (14), Trump's plan is to end terrorism by radical Muslims in America. Based on this example, it implies the functions of acclaim that denotes an increase of Trump's benefit.
E.g. (13) Clinton: "I want to get everybody out of the shadows, get the economy working, and not let employers like Donald exploit undocumented workers, who has hurt them, but also have hurt American workers" (ibid.).

E.g. (14) Trump: "We are going to stop radical Islamic terrorism in this country" (ibid.).

The policy issue of general goals is considered in the two examples $(15,16)$. Clinton in example $(15)$ argues that one of the well-known trades with America's neighbours is energy rather than with all other countries in the world. At this time, she employs the acclaim function which raises her benefit. On the contrary, in example (16), Trump employs the same function, but increases his benefit, when he stresses on the country's border and announces that Americans will have no country if the country has an open border or without a fixed border. This policy expresses Trump's general goal.

E.g. (15) Clinton: "You know, we trade more energy with our neighbours than we trade with the rest of the world combined" (ibid.).

E.g. (16) Trump: "We have no country if we have no border" (ibid.).

Table 3 reports detailed data about the three forms: past deeds, future plans, and general goals. The table shows that past deeds comprised $35.5 \%$ of policy issues ( $60 \%$ for Trump versus $40 \%$ for Clinton), future plans achieved $40.5 \%$ of policy utterances (35.5\% for Trump versus $64.5 \%$ for Clinton), and general goals had $24 \%$ of occurrences $(80 \%$ for Trump versus $20 \%$ for Clinton).

The third hypothesis is supported according to the data presented in Table 3 in which general goals are 70\% used for acclaims ( $86 \%$ for Trump versus $14 \%$ for Clinton), while $20 \%$ used for attacks (100\% for Trump versus $0 \%$ for Clinton), and $10 \%$ used for defences ( $0 \%$ for Trump versus $100 \%$ for Clinton).

With regards to the second research question, the rate of occurrence for forms of an image or a character (personal qualities, leadership abilities, and ideals) are scrutinized. Some selected samples that elucidate these forms are:

E.g. (17) Clinton: "So I think we are both a nation of immigrants and we are a nation of laws and that we can act accordingly" (ibid.).

E.g. (18) Trump: "The border — as you know, the Border Patrol agents, 16,500-plus ICE last week, endorsed me" (ibid.).

Each of the two examples $(17,18)$ indicates the personal qualities of the character or image of the two candidates. In the former example, Clinton describes her personal opinion about immigrants and law that Americans can act accordingly. This opinion is regarded as an acclaim which increases Clinton's benefit. Similarly, Trump's opinion in the later example, which is reflected as a personal image as he talks about the personal endorsements of more than 16,500 agents of the Border Patrol, is viewed as an acclaim which increases Trump's benefit.

Another two examples $(19,20)$ illustrate the character of leadership ability. Clinton in example (19) argues that putting immigrants, who are in the shadows, in the proper economy will be suitable for the immigrants, thus preventing employers from exploiting them and minimising the effects on the Amer- 


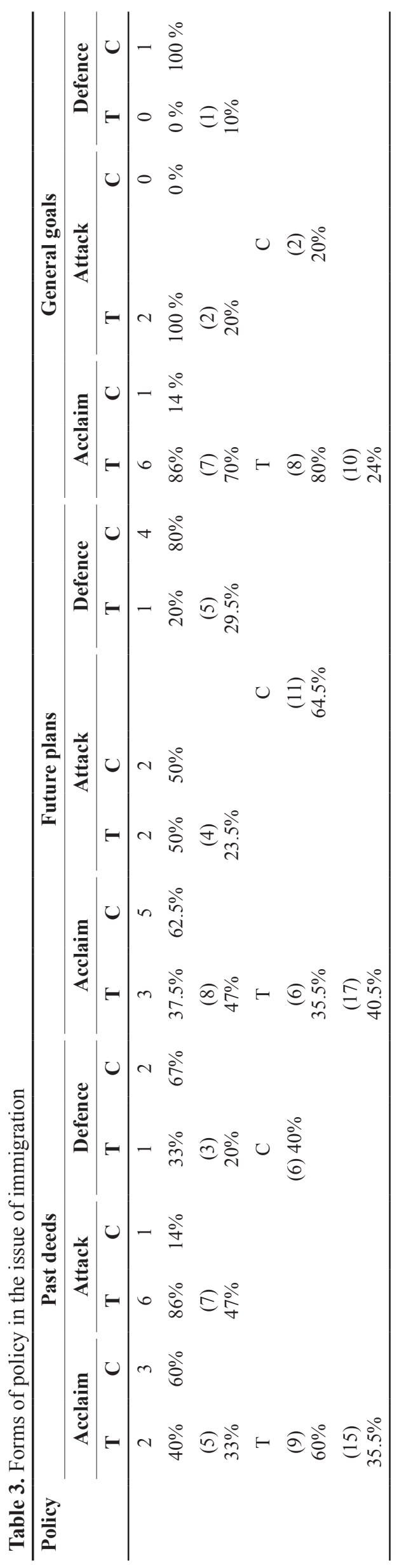

icans' income. This statement involves the function of acclaim which increases Clinton's benefit. She constantly appears to give solutions to address current problems. Her sympathy for the migrants is clear when she aims to help those who are in need of help. However, Trump, in example (20), is unlike his rival Clinton, plays the blame game by insinuating the negative traits of immigrants and to simply close the borders. Here, he reduces Clinton's benefit and increases his by using the two functions of attack and acclaim correspondingly. He emphasizes on the strong borders to prevent drugs and illegal immigrants to pour into America. In addition, he emphasizes that he will not give amnesty. Although Trump's statements may indicate a sense of patriotism, his statements reveal a tougher image or character of Trump's leadership ability.

E.g. (19) Clinton: "Now, what I am also arguing is that bringing undocumented immigrants out from the shadows, putting them into the formal economy will be good, because then employers can't exploit them and undercut Americans' wages" (ibid.).

E.g. (20) Trump: "We have to have strong borders. We have to keep the drugs out of our country. We are - right now, we're getting the drugs, they're getting the cash. We need strong borders. We need absolute - we cannot give amnesty" (ibid.).

Another image or character used by the two candidate in these debates is ideals. Example (21) shows Clinton's positive values and moralities that she supports and advocates the Americans to respect each other. Here, she declares the greatness of America to the whole world. She calls people to cooperate and recognise Americans' diversity. Additionally, this example reflects Clinton's use of the function of acclaim which leads to an increase in her benefit. On the other hand, Trump, in example (22), exposes his "police-like" and one-sided attitude where he stresses on law enforcement as priority in America. He uses the acclaim function too, which raises his benefit.

Ex. (21) Clinton: "That's why - to go back to your question - I want to send a message - we all should — to every boy and girl and, indeed, to the entire world that America already is great, but we are great because we are good, and we will respect one another, and we will work with one another, and we will celebrate our diversity" (The New York Times, 2016b).

Ex. (22) Trump: "We are a country of laws" (The New York Times, 2016c).

Then, Table 4 finds that the issue of immigration addresses images or characters of personal qualities in $29 \%$ of statements (30.5\% Trump versus $69.5 \%$ Clinton), leadership ability in $26.5 \%$ of statements ( $62 \%$ Trump versus $38 \%$ Clinton), and ideals in $44.5 \%$ of statements (54\% Trump versus $46 \%$ Clinton).

The fourth hypothesis is partially supported in accordance to the data showed in Table 4. Trump and Clinton here utilize ideals more often to attack immigrants than to acclaim and defend in which acclaim represents $37 \%$ that implies $46 \%$ for Trump versus $54 \%$ for Clinton, attack indicates $48.5 \%$ that involves $53 \%$ for Trump versus $47 \%$ for Clinton, and defence refers to $14.5 \%$ which includes $80 \%$ for Trump versus $20 \%$ for Clinton. 


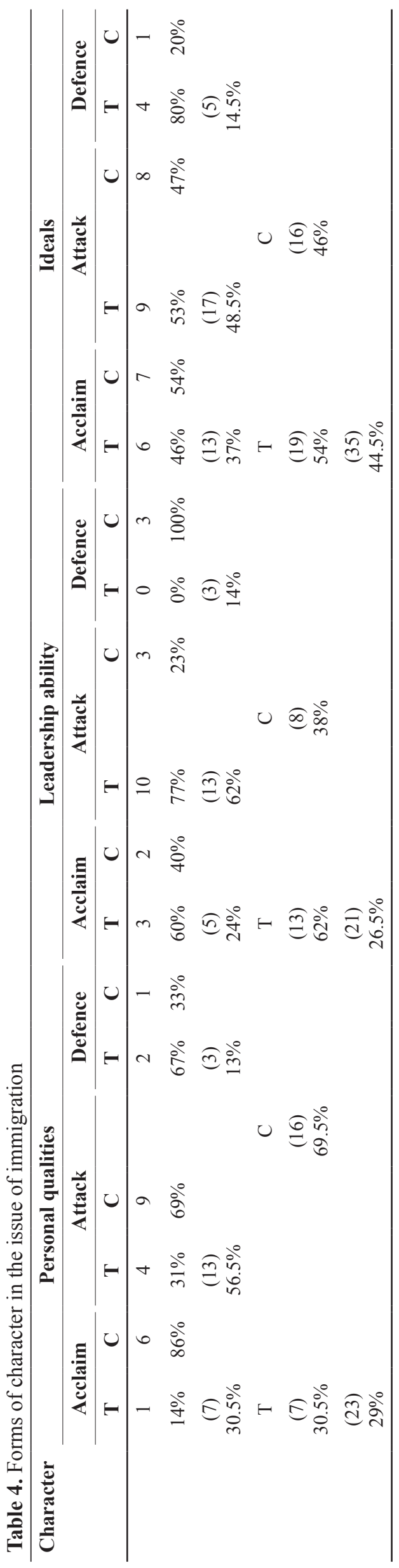

\section{CONCLUSION}

The present study provides a new perspective to our knowledge of presidential debates generally and immigrants' issue particularly. This study reveals that some functions and topics of Benoit's (2007a) functional theory that are tested on the speeches of the two candidates regarding the issue of immigration in the U.S. 2016 presidential debates are impracticable. The prediction of functional theory that acclaims occur more often than attacks whereas the defences are the least occurrence is not confirmed in the data of this study. Another prediction of this theory that is policy occurs more than character is also not confirmed. This theory recognizes that the two candidates in these debates can subjectively choose to address character more than policy or to address them at the same level. For Benoit (2017), in issues of presidential races, it is expected to emphasize character more than policy.

Concerning the classification of forms of both policy and character, which is remarkable, no predictions are made here by the functional theory. In the 2016 U.S. presidential debates, with regards to the general goals, the candidates use acclaims more than attacks and less on defences. While regarding the ideals, the candidates operate more on defences than acclaims and attacks. It is not easy to attack ideals or goals, in which the candidates are more probably "to acclaim a goal of more jobs or an ideal of justice than to attack these ideas" (Benoit, 2017). The importance of this study lies in adding new horizons of inconsistency of some hypotheses of functional theory to the issue of immigration in the U.S. 2016 presidential debates.

\section{REFERENCES}

Allcott, H., \& Gentzkow, M. (2017). "Social Media and Fake News in the 2016 Election." Journal of Economic Perspectives, 31(2): 211-36.

Benoit, W. L. (2003). Topic of presidential campaign discourse and election outcome. Western Journal of Communication (includes Communication Reports), 67 (1), 97-112.

Benoit, W. L. (2007a). Communication in political campaigns (Vol. 11). Peter Lang.

Benoit, W. L. (2017). A Functional Analysis of 2016 Direct Mail Advertising in Ohio. American Behavioral Scientist

Benoit, W. L., \& Airne, D. (2005). A functional analysis of American vice presidential debates. Argumentation and Advocacy, 41(4), 225-236.

Blendon, R. J., Benson, J. M., \& Casey, L. S. (2016). Health care in the 2016 election-a view through voters' polarized lenses. New England Journal of Medicine, 375(17), e37.

Burden, B. C., Crawford, E., \& DeCrescenzo, M. G. (2016, December). The Unexceptional Gender Gap of 2016. In The Forum (Vol. 14, No. 4, pp. 415-432).

Caldwell, Leigh Ann and Jane C. Timm (2016). Crash Course 2016: Where Donald Trump, Hillary Clinton Stand on the Issues. [Online] Available: http://www. nbcnews.com/storyline/2016-presidential-debates/pres- 
idential-debate-guide-where-donald-trump-hillary-clinton-stand-issues-n653536 (July 25, 2017).

Clarke, M., \& Ricketts, A. (2016). Understanding the Return of the Jacksonian Tradition. Orbis. 61(1), 13-26.

Crowson, H. M., \& Brandes, J. A. (2017). Differentiating Between Donald Trump and Hillary Clinton Voters Using Facets of Right-Wing Authoritarianism and Social-Dominance Orientation: A Brief Report. Psychological Reports, 120(3), 364-373.

Enli, G. (2017). Twitter as arena for the authentic outsider: exploring the social media campaigns of Trump and Clinton in the 2016 US presidential election. European Journal of Communication, 32(1), 50-61.

Ghayad, R., Cragg, M., \& Pinter, F. (2016). Elections and the Economy: What to do about Recessions? The Economists' Voice, 13(1), 9-25.

Harnish, A. (2017). Ableism and the Trump phenomenon. Disability \& Society, 32(3), 423-428.

Huang, C. H. (2017). Disillusionment and Disaggregation: Why Did Asian Americans Vote for Trump?. CMC Senior Theses. 1514.

Jacobs, N., \& Ceaser, J. W. (2016, December). The 2016 Presidential Election by the Numbers and in Historical Perspective. In The Forum (Vol. 14, No. 4, pp. 361-383).

Klar, S., Weber, C. R., \& Krupnikov, Y. (2016, December). Social Desirability Bias in the 2016 Presidential Election. In The Forum (Vol. 14, No. 4, pp. 433-443).

Landis J, Koch G (1977). The measurement of observer agreement for categorical data. Biometrics 33:159-74.

Lee, C., \& Benoit, W. L. (2005). A functional analysis of the 2002 Korean presidential debates. Asian Journal of Communication, 15 (2), 115-132.

Merelli, Annalisa (2016). All the questions Trump and Clinton faced at the second presidential debate of 2016. [Online] Available: https://qz.com/805037/second-presidential-debate-2016-what-questions-were-
asked-of-donald-trump-and-hillary-clinton/(March 13, 2017).

Powers, E. M., Moeller, S. D., \& Yuan, Y. (2016). Political Engagement During a Presidential Election Year: A Case Study of Media Literacy Students. Journal of Media Literacy Education, 8(1), 1-14. [Online] Available: http:// digitalcommons.uri.edu/jmle/vol8/iss1/1 (May 22, 2017).

Quam, J., \& Ryshina-Pankova, M. (2016). "Let Me Tell You.": Audience Engagement Strategies in the Campaign Speeches of Trump, Clinton, and Sanders. Russian Journal of Linguistics, 20(4), 140-160.

Reinemann, C., \& Maurer, M. (2005). Unifying or Polarizing? Short-Term Effects and Post Debate Consequences of Different Rhetorical Strategies in Televised Debates. Journal of Communication, 55(4), 775-794. http://onlinelibrary.wiley.com/doi/10.1111/j.14602466.2005.t b03022.x.

Slutsky, P., \& Gavra, D. (2017). The Phenomenon of Trump's Popularity in Russia: Media Analysis Perspective. American Behavioral Scientist, 0002764217693281.

The New York Times (2016a). The first 2016 presidential debate. [Online] Available: http://www.nytimes. com/2016/09/27/us/politics/transcript-debate.html. (October 24, 2016).

The New York Times (2016b). The second 2016 presidential debate. [Online] Available: http://www.nytimes. com/2016/10/10/us/politics/transcript-second-debate. html?_r=0. (October 23, 2016).

The New York Times (2016c). The third 2016 presidential debate. [Online] Available: http://www.nytimes. com/2016/10/20/us/politics/third-debate-transcript.htm$1 ? \_r=0$. (October 24, 2016).

Zarefsky, D. (2016). How It All Began: The Origins of Presidential Campaigning in the United States. In W. L. Benoit (Eds.), Praeger Handbook of Political Campaigning in the United States, 1. 